\title{
STATISTICAL DISCRIMINATION OF LATEX BETWEEN HEALTHY AND WHITE ROOT INFECTED HEVEA BRASILIENSIS TREE BASED ON PROTEIN CONCENTRATION
}

\author{
M. S. Sulaiman ${ }^{1, *}$, N. K. Madzhi ${ }^{2}$, R. Sajari ${ }^{3}$, and N. E. Abdullah ${ }^{2}$ \\ ${ }^{1}$ Faculty of Electrical Engineering, Universiti Teknologi MARA, 23000 Dungun, Terengganu, \\ Malaysia \\ ${ }^{2}$ Faculty of Electrical Engineering, Universiti Teknologi MARA, 40450 Shah Alam, Selangor, \\ Malaysia \\ ${ }^{3}$ Biotechnology Unit Lembaga Getah Malaysia, Selangor, Malaysia
}

Published online: 17 October 2017

\begin{abstract}
White root disease is a critical factor of infection to rubber trees in Malaysia. Therefore, research represent the identification of healthy and infected rubber trees is very significant in order to maintain the yield of rubber tree latex. A total of 60 samples from healthy and white root disease (WRD) infected rubber tree respectively were tested using uv-vis spectrophotometer to measure the protein concentration. Statistical analyses were carried out to determine the relationship of the protein concentration with the health condition of the rubber tree. The results indicates that, both healthy and white root disease infected tree shows discrimination by looking at the mean difference and p-value from paired sample t-test. Based on this experiment, suitable sensor could be developed in order to identify the health condition of rubber tree.
\end{abstract}

Keywords: protein concentration; hevea brasiliensis; white root disease; uv-vis spectrophotometer; t-test.

Author Correspondence, e-mail: shemi@tganu.uitm.edu.my

doi: http://dx.doi.org/10.4314/jfas.v9i5s.58 


\section{INTRODUCTION}

Rubber tree or Hevea brasiliensis is a tropical crop from the Amazon forest, South America. The name 'rubber' was given to natural rubber by Priestly, in 1770 [1]. Rubber tree has been the main source of natural rubber for use worldwide. South East Asia is the main producer of natural rubber in the world and Malaysia is one of it [2].

One of the leading problems faced by the rubber tree is root disease [1]. Root disease is fatal and one of the most serious of all diseases in rubber plantation. The cause for this disease is fungus which initially infects the surface of the root. After some time, they penetrate the wood tissue that will cause the root to rot and lastly kill the tree. By root contact, the disease could spread from one tree to another. The tree could also be infected by the spores which enter the root through any exposed tissue in the stem or branch resulting from wounds. There are six types of root diseases that have been detected to infect rubber tree. However, the three major root diseases are white, red and brown root disease. The colour of the causal fungi determines the name of the root disease. White root disease caused by Rigidoporus lignosus is a well-known and most destructive agent of trees and agricultural crops especially for rubber trees or also known as Hevea brasiliensis. It was also reported to have aggressively killed several agriculture crops and fruit trees.

Natural rubber latex (NRL) has been used commercially for more than a century. It is composed of about $36 \%(\mathrm{w} / \mathrm{v})$ of rubber fraction, $5 \%(\mathrm{w} / \mathrm{v})$ of non-rubber components such as proteins, lipids and sugar, and 59\% (w/v) of water [3]. It contains rubber particles, non-rubber particles, cytoplasmic C-serum, organelles, proteins, and lipids. Latex may be separated into three main phases by a simple high speed centrifugation: the top cream comprised of rubber particles (Zone 1-3) and Frey-Wyssling particles, the intermediate cytoplasmic C-serum, and the bottom fractions containing lutoids. At least 186 proteins have been reported to be present on rubber particles and 169 have been extracted from lutoids and the bottom fractions. Hevein belongs to the lutoid proteins and represents approximately $20 \%$ of the dry matter of the bottom fractions [4]. Protein concentration in B-serum and C-serum latex need to be prepared by collecting from field grown trees in chilled flask. Fresh latex was fractionated by centrifugation at 44,000 g (19,000 r.p.m) at 4 degree Celsius and this would lead to the separation of three distinct parts upon high-speed centrifugation [5] [6]. This demonstrates the 
process of fractioning latex into upper layer, C-serum and bottom fraction (B-serum).

There are changes in the content and properties of the protein between lutoid-body fractions from four different rubber clones. This can be proven by looking at Latex from clone GT.1 that has a higher beta-1, 3-glucanase content than those from the other three clones which are from RRIM 600, PR 261 and LCB 1320 that was collected in Selangor, Malaysia and Western Java, Indonesia [7]. By looking at this condition, it appears that changes in the concentration of protein in this fraction can be attributed to a change in the latex protein if it is infected.

There are past and present efforts in the development of methods for quantification of natural rubber latex (NRL) protein and with respect to NRL product, total protein typically refers to protein that is measured using a chemical method such as the Modified Lowry method that measures total protein content by a relatively simple and accurate. This affirmed that the analysis of several sample of ammoniated and non-ammoniated NRL proteins demonstrated a good correlation and confirmed suitability of the Lowry method for determination of NRL proteins [8] [9]. Bradford micro-assay can also be used to determine protein content. By adding Bradford reagent, the colour of the protein solution develops into violet colour. The absorbance of the solution was measured at $592 \mathrm{~nm}$ by UV-VIS spectrophotometer. The amount of protein was determined by comparison of the absorbance of the samples with a calibration curve of BSA [10]. By estimating the protein concentration, this will lead to the determination of specific activity of enzyme and can be evaluated by using Lowry's method with Bovine Serum Albumin (BSA) as a standard. In the experiment, absorbance was read at $660 \mathrm{~nm}$ using JENWAY- 6305 UV-VIS Spectrophotometer [11]. Protein concentration is typically measured by combining a small sample of the homogenate with a chemical reagent that changes colour in proportion to the amount of protein present.

The protein content of the liver homogenate will be determined by comparing the absorbance of homogenate sample to the absorption coefficient determined from a standard curve. The concentration of a solution can be calculated using the Beer-Lambert Law:

$$
\mathrm{A}=\varepsilon \times 1 \times \mathrm{c}
$$

Where $\mathrm{A}$ is the absorbance, $\varepsilon$ is the molar absorption coefficient $(\mathrm{M}-1 \mathrm{~cm}-1), 1$ is the cell pathlength $(\mathrm{cm})$ and $\mathrm{c}$ is the molar concentration [12] [13]. From here we can see that there 
are a variety of methods to determine measurements for latex protein. However, based on the literature review, it was found that the quantification of protein can be best done by using Bradford assay method because of its simplicity and efficiency.

Until today, there is a lack of investigation involving protein concentration in finding the relationship between protein concentrations of natural rubber content in latex with respect to root diseases infected rubber trees. Therefore, this research proposes a study in finding relationship between protein concentrations of natural rubber content with respect to latex produced by root diseases infected rubber tree by using statistical analysis.

\section{METHODOLOGY}

Fig. 1 is flowchart of the research to distinguish between white root disease (WRD) infected and healthy trees starting from collecting samples at the Rubber Research Institute in Kota Tinggi, Johor's down to data analysis. The next subsection describe each part of the research flowchart.

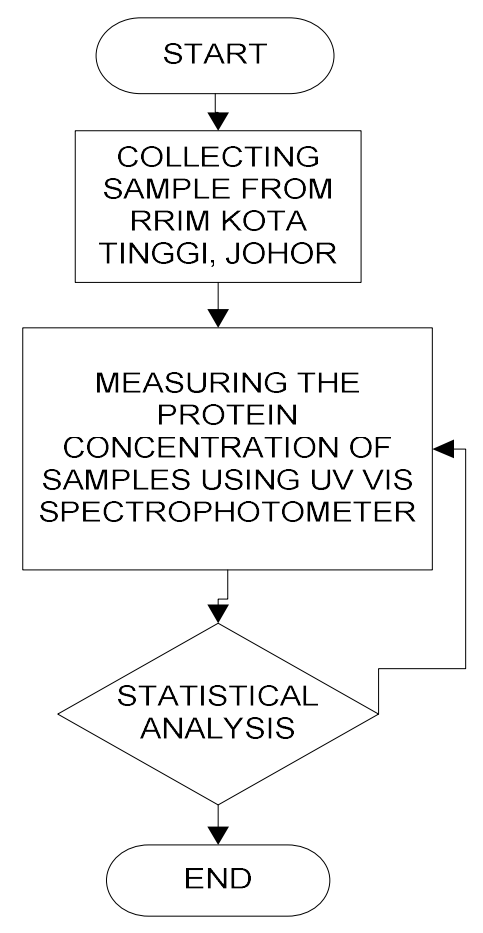

Fig.1. Flowchart of research

\subsection{Determination of White Root Disease and Healthy Rubber Tree}

The tenacity, of white root disease was done with the assistance of experts from Integrated 
Pest and Disease Management Program (IPDM) of Rubber Research Institute Malaysia (RRIM). Sample classes were resolute by tree morphology and the presence of white root disease fungus. Basically, there are 5 types of infection for white root disease. Fungus infection is evaluated based on how many segmentations $(a, b, c, d)$ at the root have occurred. As an example, type 3 infection is tenacious if any three out of four segmentation have been infected by white root fungus. The tree is verbally expressed to be type 5 infected if it is unable to engender latex and dying. Fig. 2 shows the segmentation of root area for infection type tenaciousness.

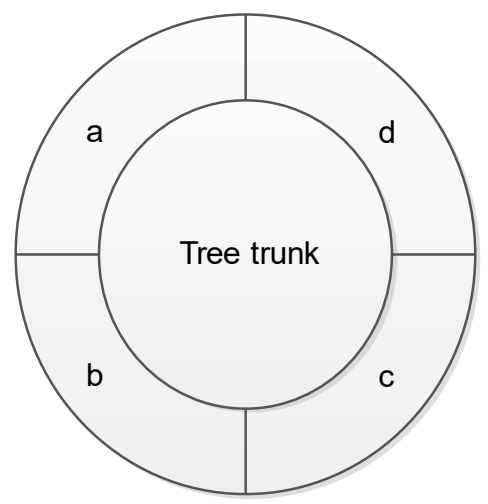

Fig.2. Tree root area (top view) segmentation for white root infection categories

\subsection{Samples Collection}

An experiment was conducted at Rubber Research Institute Malaysia (RRIM) Kota Tinggi in June 2014 and January 2015. The experiment was tested on 30 rubber trees from 3 different clones which are 2002, 2020, and 3001. These clones were obtained from three main stations in RRIM Kota Tinggi named Pelepah, Permatang and Pemandi. The clones were chosen based on the availability of healthy and white root disease samples in their group.

\subsection{Samples Preparations}

Predeterminations of white root disease infected trees were done several days before sample collection by a trained RRIM officer based on the tree morphology and the presence of white root disease fungus. In other words, if there was a white root disease from a specific clone, healthy samples from the same clone was also obtained. Latex samples were collected directly from tree trunk at the point where the tree was usually tapped. The container used to store latex was ensured to be uncontaminated. A minimum amount of $60 \mathrm{ml}$ of latex must be 
collected from each tree in order to do the test. Preservative was inserted into the samples to avoid coagulation and maintain its freshness.

\subsection{Instrumentation}

The UV-1800 ultraviolet-visible spectrophotometer made by Japan's SHIMADZU Corporation and several personal computers were adopted as the experimental apparatus. The parameters of the spectrophotometer were set as follows: the wavelength coverage for test is from $1100 \mathrm{~nm}$ to $350 \mathrm{~nm}$ with step-length of $1 \mathrm{~nm}$. The scanning speed is set as fast and the sampling interval is set to be automatic.

\subsection{Measurement of Protein Concentration}

Field collected ammoniated latex was mixed with Triton X-100 solution (one part of latex to four parts) with $0.125 \%$, followed by stirring at $4^{\circ} \mathrm{C}$ for 1 hour. The entire mix sample (Latex and Triton $\mathrm{X}-100)$ is stirred to ensure that the protein from all samples is preserved. The time of the stirring process would be 30 minutes. The centrifuge was set at RPM (14 x 1000) and RCF $(18 \times 1000)$. The mixture was centrifuged at $44000 \mathrm{~g}$ for 1 hour at $4{ }^{\circ} \mathrm{C}$ to recover the supernatant (serum phase). While waiting the centrifuge process, BSA standard was weighted at $0.006 \mathrm{mg}$. But in order to dilute $0.002 \mathrm{mg} / \mathrm{ml}$, distill water need to be added. A $300 \mathrm{ml}$ of distill water were mixed with the $0.006 \mathrm{mg}$ of BSA to produce a solution of $0.002 \mathrm{mg} / \mathrm{ml}$.

After centrifuging, the samples will have 3 layers which are upper fraction, c- serum and bottom fraction (lutoids). By using micropipette, pipette the c- serum fraction only. The upper fraction was removed to ease the process of c- serum extraction. All samples from C-Serum and BSA standard for healthy and white root disease were transferred to a new tube. BSA standard was diluted with $20 \mathrm{ml}$ distill water to get $2 \mathrm{mg} / \mathrm{ml} .20 \mu 1$ BSA standard that had been diluted will be added with $1 \mathrm{ml}$ of Bradford and vortex. The mix samples of white root disease, healthy and BSA standard which have been mixed with Bradford assay will be tested using uv-vis spectrophotometer to measure the protein concentration of each sample. 
Table 1. Table below shows the $1 \mathrm{ml}$ standard assay

\begin{tabular}{|l|l|l|l|l|l|}
\hline Tube & $\begin{array}{l}\text { Standard } \\
\text { Volume }(\mu l) \\
(\mathbf{V})\end{array}$ & $\begin{array}{l}\text { Source of } \\
\text { standard } \\
(\mathrm{mg} / \mathrm{ml}) \\
(\mathbf{M} \mathbf{1})\end{array}$ & $\begin{array}{l}\text { Diluent } \\
\text { Volume }(\mu l)\end{array}$ & $\begin{array}{l}\text { Final (Protein) } \\
(\mu \mathrm{g} / \mathrm{ml}) \\
(\mathbf{M} \mathbf{)})\end{array}$ & $\begin{array}{l}\text { Final }(\mu l) \\
(\mathbf{V 2})\end{array}$ \\
\hline 1 & $70 / 20$ & 2 & 0 & 2000 & 100 \\
\hline 2 & 75 & 2 & 25 & 1500 & 100 \\
\hline 3 & 70 & 2 & 70 & 1000 & 100 \\
\hline 4 & 35 & Tube 2 (S2) & 35 & 750 & 100 \\
\hline 5 & 70 & Tube 3 (S3) & 70 & 500 & 100 \\
\hline 6 & 70 & Tube 5 (S5) & 70 & 250 & 100 \\
\hline 7 & 70 & Tube 6 (S6) & 70 & 125 & 100 \\
\hline 8 (Blank) & - & - & $70 / 20$ & 0 & 100 \\
\hline
\end{tabular}

Table 1 shows the mixture of BSA standard volume needed in order to get 100 of final volume. This is the standard protocols using Bio-Rad quick start Bradford protein assay for diluting the protein standard in order to plot the standard curve using UV-VIS spectrophotometer and it is done by using dilution equation, where a certain concentration of a solution for a given concentration solution can be calculated as follows:

$(M 1)(V 1)=(M 2)(V 2)$

$(2 m g / m l)(x)=(1.5 m g / m l)(100 \mu l)$

$x=$ Standard Volume $=75 \mu l$ (Standard volume in tube 2)

\subsection{Statistical Analysis}

Statistical analysis was used to discriminate between the two groups i.e.; healthy and white root disease. Data obtained from UV-VIS spectrophotometer experiment was proceeding to the statistical analysis by using IBM SPSS software. Two steps involved to discriminate all the data into healthy and white root disease group were normality test and error bar plot.

\section{RESULTS AND DISCUSSION}

\subsection{Normality Test}

From 60 trees that were obtained, 30 samples from healthy and white root disease infected trees were extracted. The protein concentration values were extracted using UV-VIS spectrophotometer as in Table 2. These obtained protein concentration values were firstly 
evaluated using a normality test. Normality test using Kolmogorov-Smirnov algorithm was done to determine normally distribution for any sample population if the p-value is more than 0.05. As shown in Table 3, both healthy and white root disease samples has a p-value of more than 0.05 . Thus, this indicates the data follows a normal distribution and with such, other parametric tests can be applied [14] [15] 16].

Table 2. Extracted protein concentration from healthy and white root disease samples

\begin{tabular}{|c|c|c|}
\hline & \multicolumn{2}{|c|}{ Concentration $\mathbf{( m g m l}^{-1}$ ) } \\
\hline No. & Healthy & WRD \\
\hline 1 & 1899.21 & 1692.53 \\
\hline 2 & 1724.94 & 1207.3 \\
\hline 3 & 1740.52 & 1395.53 \\
\hline 4 & 1792.19 & 996.71 \\
\hline 5 & 2131.73 & 1480.19 \\
\hline 6 & 1824.04 & 1717.94 \\
\hline 7 & 1803.11 & 1255.27 \\
\hline 8 & 1840.07 & 2104.24 \\
\hline 9 & 1916.1 & 1588.24 \\
\hline 10 & 1732.32 & 1481.51 \\
\hline 11 & 1639.29 & 1041.2 \\
\hline 12 & 1862.39 & 2022.39 \\
\hline 13 & 1902.82 & 2027.52 \\
\hline 14 & 1856.23 & 1301.3 \\
\hline 15 & 1795.02 & 1656.18 \\
\hline 16 & 1841.26 & 1183.13 \\
\hline 17 & 1735.85 & 1027.46 \\
\hline 18 & 1752.59 & 1359.41 \\
\hline 19 & 1918.87 & 1746.18 \\
\hline 20 & 1646.52 & 1924.22 \\
\hline 21 & 1860.15 & 1599.61 \\
\hline 22 & 1842.4 & 1722.5 \\
\hline 23 & 1744.71 & 1069.39 \\
\hline 24 & 1816.61 & 1364.4 \\
\hline 25 & 1791.71 & 1664.89 \\
\hline 26 & 1758.5 & 1877.95 \\
\hline 27 & 2095.93 & 1785.65 \\
\hline 28 & 1799.71 & 1968.39 \\
\hline 29 & 2056.77 & 1428.06 \\
\hline 30 & 1741.06 & 1053.06 \\
\hline & & \\
\hline
\end{tabular}


Table 3. Normality test of protein concentration value for each categories of samples.

Tests of Normality

\begin{tabular}{|l|r|r|r|r|r|r|}
\hline & \multicolumn{3}{|c|}{ Kolmogorov-Smirnov $^{\text {a }}$} & \multicolumn{3}{c|}{ Shapiro-Wilk } \\
\cline { 2 - 7 } & Statistic & \multicolumn{1}{c|}{ df } & \multicolumn{1}{c|}{ Sig. } & Statistic & \multicolumn{1}{c|}{ df } & \multicolumn{1}{c|}{ Sig. } \\
\hline Healthy & .151 & 30 & .078 & .912 & 30 & .017 \\
WRD & .087 & 30 & $.200^{*}$ & .957 & 30 & .257 \\
\hline
\end{tabular}

*. This is a lower bound of the true significance.

a. Lilliefors Significance Correction

\subsection{Error Bar Plots Analysis}

Fig. 3 shows the result of applying error bar plot while Table 3 represents the descriptive measurements of the test. By observation, the lower confidence limit of healthy samples (1824.109) does not overlap with the upper confidence limit of the white root disease (1603.576). Therefore, implying both sample populations means range differed from each other.

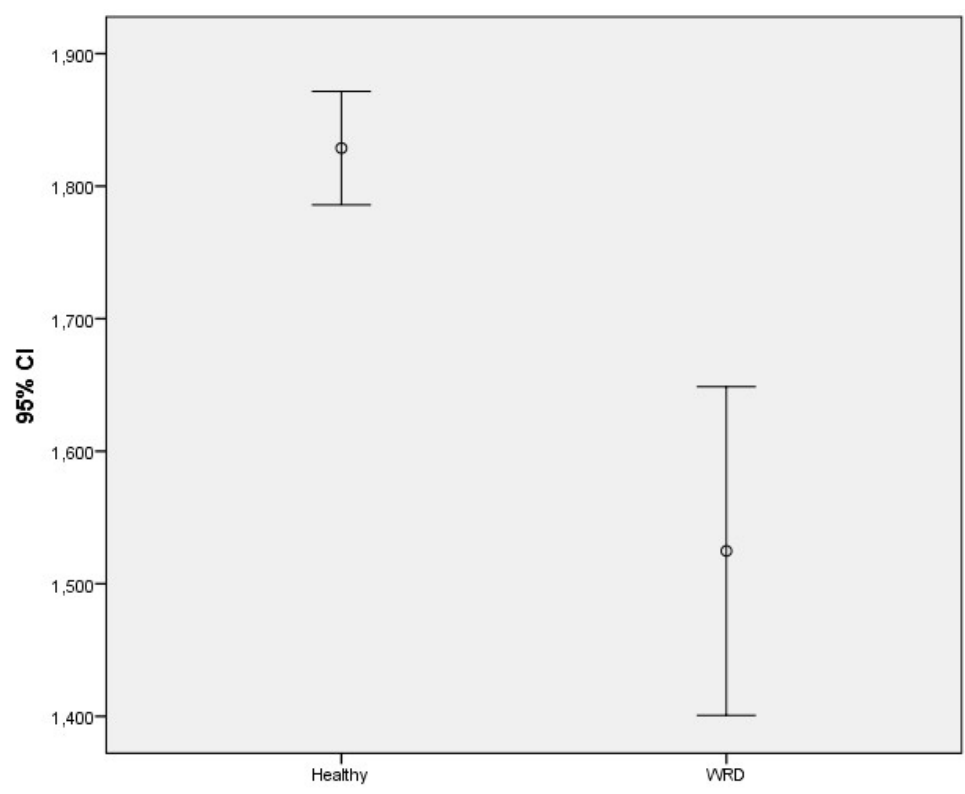

Fig.3. Error bar plot for healthy and white root disease protein concentration values. 
Table 3. Measurements of error bar plot for healthy and white root infected samples

\begin{tabular}{crll}
\hline & Mean \pm Std. Error & UCL & LCL \\
\hline Healthy & $1828.753 \pm 20.935$ & 1871.571 & 1785.935 \\
WRD & $1524.745 \pm 60.632$ & 1648.752 & 1400.738 \\
\hline
\end{tabular}

In order to recognize the features between two groups of sample, error plot was utilized as a first method of analysis. Error plot provides a range of values based on the sample mean and standard deviation.

For numerical analysis, data for this work is then further tested using paired samples t-test and the outcomes are depicted in Table 4. With respect to table, there was a significant average difference between Healthy and WRD since the mean difference is 304.007 and p-value for this test is less than 0.001 which indicates there is significant evidence that both samples population can be discriminated from each other.

Table 4. Paired Samples Test for Healthy and White Root Diseases (WRD)

\begin{tabular}{ccccccc}
\hline (1) & (2) & $\begin{array}{c}\text { Mean } \\
\text { Difference }\end{array}$ & $\begin{array}{c}\text { Std. } \\
\text { category }\end{array}$ & $\begin{array}{c}\text { Sig. } \\
\text { category }\end{array}$ & $\begin{array}{c}\text { (I-tailed) } \\
\text { (p-value) }\end{array}$ & \multicolumn{2}{c}{$\begin{array}{c}\text { Confidence } \\
\text { Interval }\end{array}$} \\
\cline { 5 - 7 } & & & & LCL & UCL \\
\hline Healthy & WRD & 304.007 & 58.279 & .000 & 184.81 & 423.2 \\
\hline
\end{tabular}

\section{CONCLUSION}

The investigation of discrimination between healthy and white root disease (WRD) infected rubber tree latex for 60 trees tested indicates that there are a good correlation between white root disease infection and protein concentration in latex. By statistical analysis, the results showed a very distinguishable value for both cases. There were no overlap in error bar between both cases, and p-value was less than 0.05 of paired samples test, signalling the discrimination between both cases. This indicates that white root disease infection has effect on rubber latex by looking at the protein concentration level.

Based on the experiment, there are discrimination between healthy and white root disease. By developing a suitable sensor, this would be a good help for the rubber industry to improve the 
method of crop monitoring and would lead to the increasing of production of natural rubber latex.

\section{ACKNOWLEDGEMENTS}

The authors would like to thank all RRIM staff especially the Biotechnology Unit of Rubber Research Institute of Malaysia (RRIM) at Sg. Buloh and also the Crop Improvement and Protection Unit staff for their valuable information, suggestions, guidance and also for providing the data prior to the experiment of this research.

\section{REFERENCES}

[1] Daud N W, Mokhatar S J, and Ishak C F. Assessment of selected Hevea brasiliensis (RRIM 2000 Series) seeds for rootstocks production. African Journal of Agricultural Research, 2012, 7(21):3209-3216

[2] Omorusi I V. Effects of white root rot disease on hevea brasiliensis. In N. K. Dhal, \& S. C. Sahu (Eds.), Plant Science, Croatia: Agricultural and Biological Science, IntechOpen, 2012.

[3] Danwanichakul D, Rattanaphan O, Srisatjang J, and Danwanichakul P. Extraction of protein from skim natural rubber latex using PEG as a surfactant via low speed centrifugation and continuous flow. Journal of Applied Polymer Science, 2014, 131(4):1-9

[4] Berthelot K, Peruch F, and Lecomte S. Biochimie, 2016, 127, 258-270, doi:10.1016/j.biochi.2016.06.006

[5] Daruliza K M A, Lam K L, Priscilla J T, Ong M T, Yang K L, and Sunderasan E. Anti-fungal effect of hevea brasiliensis latex c-serum on aspergillus niger. European Review for Medical and Pharmacological Sciences, 2011, 15(9):1027-1033

[6] Tang C, Xiao X, Li H, Fan Y, Yang J, Qi J, and Li H. Comparative analysis of latex transcriptome reveals putative molecular mechanisms underlying super productivity of hevea brasiliensis. PLOS ONE, 2013, 8(9):1-18

[7] Subroto T, De Vries H, Schuringa J J, Soedjanaatmadja U M S, Hofsteenge J, Jekel P A, and Beintema J J. Enzymic and structural studies on processed proteins from the vacuolar (lutoid-body) fraction of latex of Hevea brasiliensis. Plant Physiology and Biochemistry, 2001, 39(12):1047-1055 
[8] Beezhold D H. Measurement of latex proteins and assessment of latex protein exposure. Methods, 2002, 27(1):46

[9] Sussman G L. Allergens and natural rubber proteins. Journal of Allergy and Clinical Immunology, 2002, 110(2):33-39.

[10] Kalapat N, Watthanachote L, and Nipithakul T. Extraction and characterization of proteins from skim rubber. Kasetsart Journal - Natural Science, 2009, 43(5):319-325.

[11] Nayanashree G, Thippeswamy B. Biodegradation of natural rubber by laccase and manganese peroxidase enzyme of bacillus subtilis. Environmental Processes, 2015, 2(4): $761-772$

[12] Grimsley G R, Pace C N. Spectrophotometric determination of protein concentration. In J. E. Coligan, B. M. Dunn, D. W. Speicher, \& P. T. Wingfield (Eds.), Current protocols in protein science, United States: Jon Wiley \& Sons, 2004.

[13] Kim C, Eom J B, Jung S, and Ji T. Detection of organic compounds in water by an optical absorbance method. Sensors (Besel), 2016, 16(1):61

[14] Abdullah N E, Hashim H, Madzhi N K, Sulaiman M S, Ismail F A, and Hanafiah K M. Rubber tree clone breed identification based on latex spectrum properties. Advanced Materials Research, 2015, 1113, 204-209

[15] Hashim H, Haron M A, Osman F N, Junid S A M. Classification of rubber tree leaf disease using spectrometer. In $4^{\text {th }}$ Asia International Conference on Mathematical/Analytical Modelling and Computer Simulation, 2010, 302-306

[16] Osman F N, Hashim H, Al-Junid S A M, Haron M A, Abdullah N E, Muhammad M F. A statistical approach for rubber seed clones classification using reflectance index. In $4^{\text {th }}$ Asia International Conference on Mathematical/Analytical Modelling and Computer Simulation, 2010, pp. 291-295

\section{How to cite this article:}

Sulaiman M S, Madzhi N K, Sajari R, Abdullah N E. Statistical discrimination of latex between healthy and white root infected hevea brasiliensis tree based on protein concentration. J. Fundam. Appl. Sci., 2017, 9(5S), 818-829. 